Volume 6 Issue 4, December 2019

Nationally Accredited Journal,

Decree No. B/4130/E5/E5.2.1/2019

\title{
Setting the Effectiveness of Law Position and Code Notary to the Quality of Performance
}

\author{
M. Indah Verena Ferdiyanti ${ }^{1}$, Dwi Fahri Hidayatullah ${ }^{2}$ and Amin \\ Purnawan $^{3}$
}

Abstract. This study aims to determine the readiness of governments to regulate and promote the performance of the notary through UUJN and implementation supervision performed by the Supervisory Council, how effective arrangements and Notary Code UUJN to the quality of performance of a notary. The writing method is based on the normative juridical research with a normative approach carried out by analyzing the material by reference to the norms of law - legal norms in the implementation of the code of conduct notary. The results of this study that the notary in carrying out its duties and responsibilities can not be separated from the code of conduct that has been set. But not infrequently the notary work outside their code of ethics. Actions that violate the code of conduct notary, such as signing a deed that is not done in the presence of a notary, a deed outside the office and a deed which is not in accordance with the provisions contained in Law No. 2 of 2014. This of course led to the violation of the law regarding the conduct of their duties. So supervision by the Indonesian Notary Association (INI) has an important role towards the creation of a notary who work according to the code of conduct. Monitoring carried out INI is more enforcement against notary abuse, such as giving reprimand, warning and suspension or even expulsion from membership. So supervision by the Indonesian Notary Association (INI) has an important role towards the creation of a notary who work according to the code of conduct. Monitoring carried out THIS is more enforcement against notary abuse, such as giving reprimand, warning and suspension or even expulsion from membership. So supervision by the Indonesian Notary Association (INI) has an important role towards the creation of a notary who work according to the code of conduct. Monitoring carried out THIS is more enforcement against notary abuse, such as giving reprimand, warning and suspension or even expulsion from membership.

Keywords: Notary Act (UUJN); Notary Code; Indonesian Notaries Association.

\section{Introduction}

The Republic of Indonesia as a state of law based on Pancasila and the Act. Indonesian republic state constitution in 1945 to ensure certainty, order and legal protection for every citizen. Legal certainty is one of the main objectives in the draft law states that in addition to their other goals for the creation of the rule of law and public order. Indonesia is a country of law as defined in Article 1 Paragraph 3 of the Act of 1945 means that in the life of the nation in Indonesia should be based on law, not the rule. Legal certainty is intended to provide protection for people in defending your rights.

\footnotetext{
1 Student of Master of Notary Program, Faculty of Law, University Islam Sultan Agung Semarang email indahverena166@gmail.com

${ }^{2}$ Student of Master of Law, Faculty of Law, University Islam Sultan Agung Semarang email dwifahri9293@gmail.com

${ }^{3}$ Faculty of Law, Universitas Islam Sultan Agung Semarang, Semarang
} 
The rights of the rights in question is a perfect namely the rights whose scope is clear, fixed and given. ${ }^{4}$

To ensure certainty, order, and legal protection necessary evidence is authentic writing about deeds, agreements, placement, and legal events made before or by a notary. Notary as a public official who runs the profession in providing legal services to the public, need protection and guarantees in order to achieve legal certainty. Protection guarantee legal certainty and guarantee the achievement of the workings of a notary has been regulated in the Act No. 30 of 2004 on the office of a notary. However, some provisions in the Act - the law is no longer relevant to the development of law and the needs of the community so we need a change, which is also intended to further define and establish the duties, functions,

Notary Public Officials which is the only one authorized to make an authentic deed regarding all of making agreements and determination required by the General Regulation or by the concerned desired to be stated in an authentic deed, ensure certainty the date, save and give Grosse, ${ }^{5}$ copies and excerpts, all along the deed was by a general rule not also be assigned or excluded to the official or other person. ${ }^{6}$

Notary office for the implementation of tasks in accordance with the legislation, it is necessary to control. Supervision is an activity that is preventive and curative including development activities undertaken by the Supervisory Council of the Notary. There are three tasks performed by a panel of supervisors, namely: ${ }^{7}$

- preventive surveillance

- supervision curative

- development

As noted above that the surveillance is an activity that is both preventive and curative. Preventive implies a process of coaching, curative means do sanctions against notaries in the execution of their positions if convicted of a violation of the Law No. 2 of 2014 and a violation of the Notary Code. The scope of this oversight is broader than the scope of supervision to the notary conducted by the Regional Supervisory Council as stipulated clearly and unequivocally in the Act of notary. While supervising the implementation of Notary Code made by the WCA Board Notary under Indonesian notary bond (INI). Notary honorary council whose job is to do the coaching and guidance.

The function is intended to allow supervised coaching is always to understand and therefore comply with the rules as well just listed and set in the code of conduct notary nor the provisions of the laws that apply. All were based on the laws or the meaning of

\footnotetext{
${ }^{4}$ Lili Rasyidi, Check In Darji Darmodiharjo, 2000, Et.Al. Pokok-Pokok Filsafat Hukum (Apa Dan Bagaimana Filsafat Hukum Indonesia), Jakarta: Gramedia Pustaka Utama, p.1

${ }^{5}$.Grosee is a copy of a court or an authentic deed (notary deed) having executorial power, which means that grosseitu must wear a head on it the words, "As Justice Under God Almighty", sebagaiman any verdict must wear head says ruling -said that, according to article 4 of Act No. 14 of 1970 (LN 74 LN1970 No.2951). Victor M.Situmorang and Cormentyana Sitanggang, 1993, Grosse Akta dalam Pembuktian dan Eksekusi, Molds 1, Jakarta: Rineka Cipta, p 39.

6 , Notary Regulations, Article 1 Stb 1860-31 compiled by GHS Lumban Tobin, g, in Muchlis Fatahna et al, 2003, Notaris Bicara Soal Kenegaraan, Jakarta: Watampone Press, p 253

${ }^{7}$ Habib Adjie, 2011, Hukum Notaris Indonesia, Bandung: Refika Aditama, p. 188
} 
the oath spoken and witnessed by the world witness that oath enforcement officials and witnesses specifically signed for it. While the notary supervision function is intended that in carrying out his notarial continue to comply with the provisions of applicable laws, codes of conduct when a notary public notary for proven violations will be penalized. The intent and purpose of the supervision of the notary office task is to provide direction and demand for notaries in their duties and positions his profession as a public official in order to improve the professionalism and quality of performance so as to provide certainty and legal protection for people who use services of a notary. The presence of a notary public who are trapped in behaviors or actions that violate the code of conduct, should receive strict sanctions, given the Law No. 2 of 2014 on the notary office, that the behavior of notaries in the execution of a notary office must comply with the provision. ${ }^{8}$

The above description of the background, the authors are interested in and raised a question of how Effectiveness setting Notary Act Performance Against Notary and Notary Code Violation Form has been done by the Notary?

\section{Research methods}

The method used is a normative juridical approach, the research in the assessment by referring to and basing on the norms and rules of law, regulations law in force, the theory and legal doctrine, jurisprudence and materials other literary relevant to the topic of research in accordance with normative juridical approach, the source of the data in this study is only a secondary data, which form the primary legal materials, secondary and tertiary. To obtain the material required law, is done by searching, collecting and studying the material decisions, laws, research, publications - scientific papers and documents - other written documents.

\section{Results And Discussion}

\subsection{Setting The Effectiveness Of Law On The Performance Of Position Notary}

Notary institution came from Holland and brought to Indonesia by the Dutch businessman at the beginning of the seventeenth century on August 17 1620. Hal closely related with the increase and the development work done by the Dutch companies, commonly known as VOC (Verenigde Oost Indische Compagnie) in Indonesia. Then by the Governor-General Jan Pieterszoon Coen was appointed as a Notary General Melchior Kerchem $I$ in Indonesia. The purpose and objectives of the Notary Institute in Indonesia is to meet the demand for authentic evidence for entrepreneurs to use their rights and interests arising from trade transactions they do. On November 12, 1620, the Governor-General Jan Pieterszoon Coen issued a Decree on the Notary office, which principally includes: "Notary is an independent office regardless of the registrar of the court".

\footnotetext{
8 file: /// C: / Users / asus / Downloads / 213 182-none\% 20 (1).pdf, Accessed on 30 December 2019, 20:00
} 
Furthermore, to discuss the juridical aspects of Notary Act No. 30 of 2014 jo Law of the Republic of Indonesia No. 2 In 2014 the performance of the Notary, which is now being enforced by the government to regulate the performance of a notary in Indonesia, in fact inseparable from the history and background to the UUJN it, is starting from product use laws colonial heritage that is regulation office of a notary (hereinafter abbreviated to PJN), originally adopted in Indonesia by the Dutch government during the Dutch colonial Indonesia, the PJN effect since 1st July 1860 by staat blad number 1860-3, and even after 1945, keep using PJN for notaries in Indonesia, so it was more or less (4) PJN century applied in Indonesia, then finally the Government together with the Parliament on October 6, 2004 endorsed and enacted UUJN No. 30 of 2004 on the post of notary replace PJN products Act relic of colonial to adjust to the climate of legal culture in Indonesia, with a reason to adjust the legal development, then on the 15th January 2014 enacted another Law of the Republic of Indonesia Number 2 of 2014 On amendments to the Law No. 30 of 2004, all of which was done by the government with the aim of achieving the unification of law notary office, to regulate the performance of the notary Indonesia with the hope to improve the quality of notary work through the legislation and supervision. ${ }^{9}$

In carrying out the notary office should be able to be professional with based on noble personality always perform their duties in accordance with the laws that apply at the same time uphold the professional code of ethics as a notary signs must be obeyed. Notaries need to pay attention to what is referred to as a professional conduct that has elements as follows:

- Must have strong personal moral

- Must be honest with the client nor myself

- Should be aware that maintaining the demands of professional ethics is a heavy obligation

- Must have ideals

In article 16 (1) letter a to letter m of Notary Act No. 2 of 2 2014, Notaries are required to act honestly, thoroughly, independently, impartially and safeguard the interests of the parties involved in the legal action. In addition, the notary as public officials must be sensitive, responsive, has a sharpness of thinking and able to provide an analysis of the remains of any legal phenomenon and social phenomenon that appears so will foster the brave attitude in taking appropriate action. Courage here is the courage to undertake appropriate legal actions right laws that apply through a deed strongly rejected the deed that is contrary to law, morals and ethics. ${ }^{10}$ Public confidence in the notary public or an officer is also a public trust to the deed he had done, that's why the office of a notary often called to positions of trust. Trust the government as a government agency to appoint and dismiss public confidence as a notary and notary service users.

\footnotetext{
${ }^{9}$ Henny Tanuwidjaja, Juridical Aspects of Notary Act No. 30 of 2004 Jo Act 2 of 2014 N0mor Performance Against Notary Law Journal Vol. XXX No. December 2nd, 2014

${ }^{10}$ Wawan Setiawan, 2004, Sikap Profesionalisme Notaris Dalam Pembuatan Akta Otentik, Surabaya: Media Notary, Pg. 25
} 
Volume 6 Issue 4, December 2019

Nationally Accredited Journal,

Decree No. B/4130/E5/E5.2.1/2019

In the performance of a notary with a grounding device law of notary office number 2 in 2004 in conjunction with the Act No. 30 of 2004, hereinafter referred to UUJN namely the prohibition of Notaries in position:

Letter F: concurrent positions as leaders or employees of state-owned enterprises, region-owned enterprises or private entities;

Letter G: concurrent positions as officials of Land and / or Class II Auction officials outside the seat of the Notary;

\subsection{Notary Form Code Violations During This Is Performed By Notary}

Notary is a legal profession that is very important in the legal system, given notary is a public official authorized to make an authentic deed. Thus it can be said that the notary is one of the pillars of the rule of law in Indonesia.

According Izenis, shape notary institution is divided into two main groups, namely

- Notary function, in which the government authority delegated (gedelegeerd) and thus is thought to have the truth of its contents, has the power of formal proof and has the power of execution.

- Notary professional, in this group, although the government regulates the organization, but the deed - it does not have the notarized deed as a result - a special consequence of the truth, the strength of the evidence, as well as the strength. Izenis theory based on the premise that the notary was a part of or closely related to the judicial authority / court (rechtelijke macht), as there are in France and the Netherlands. ${ }^{11}$

As a public official, a notary must always be guided by the Act - Law office of a notary public notary dank ode ethics. Article 15 UUJN, known duties and authority as a notary is authentic. Notaries also provide legal advice and explanation of laws to the party that faced him with regard to the preparation of a deed.

In carrying out his post, notaries as public officials who have been approved to serve and obey the law is realized through adherence to the norms and ethics. Notaries must have high professional ability with moral integrity, dignity and ethics of the profession so that confidence in the office should be controlled by a code of conduct notary, with a few considerations:

- Notary public officials whose job is to implement public office

- Notaries in performing their duties may not be defamed from the corps development of the legal profession

- Notaries in carrying out its duties do not defamed of institutions Notary

- Notary works by applying the law in the resulting product, the code of conduct is expected to always remembering to upholds the nobility of his duty and dignity, as well as stints in compliance with the requirements specified by law.

The code of ethics is very closely related to the execution of his duties was good, because with these codes is determined traits to be possessed by a notary public. Ethical relationship with the legal profession that the ethics of the profession is the

${ }^{11}$ Izenis In Liliana, opcit p.84 
attitude of life in the form of a willingness to provide professional service in the field of law on society with the full involvement as a service in order to carry out the task in liabilities with reflection and therefore in carrying out the profession must pay attention to the rules - the basic principles in the form of professional ethics.

Notary ethical code governing the obligations, restrictions and exclusions. The code of ethics governing the obligations of the notary. In addition code of conduct notary also establishes restrictions for notaries. Code violations that occur and are known by the Honorary Council of the Association of Regional Notary Indonesia, among others:

- A deed which is not in accordance with the law notary office, such as a deed signed by a notary, witnesses have been first prepared by another notary so stay signing of the notary.

- The signing of the deed which was not done before a notary

- A deed outside the territory

- Provisions concerning the installation of a sign in front of a notary or in an office environment. The discovery of the notary who made the nameplate that exceed a predetermined size.

- Rates unhealthy competition, where there is a notary who put up a very low tariff to get clients

- Doing publicity or promotional yourself by stating your name and position. Such as sending a wreath at a particular event

- Using the services of intermediaries such as service bureaus in finding clients

- The presence of a deed did not finish the board and tell the client about the completion of the

- Detain a person files with the intention of forcing a deed to a notary who hold the file

- Sent to the client to be signed by the client in question

- Persuading clients a deed or persuade a person to move from another notary

- Mutual dropped between notaries from one another.

Each professional group has a norm being claimant behavior of their members in carrying out professional duties. Norm is formulated in written form so-called code of professional conduct. The code of ethics of the legal profession is a form of realization ethics of the legal profession is concerned. In carrying out its obligations, legal professionals need to have:

- Human nature, not in response moral law alone, but the truth in accordance with conscience

- Fairness, it means seeking eligibility in accordance with the feeling of community

- Attitude is worth, it means seeking the determination of justice

- Honest attitude, meaning that states a right according to what it is, and avoid improper and inappropriate. ${ }^{12}$

To get less violation of the code of conduct according to the authors for socialization and supervision are carried out continuously and sustainably by Indonesian notary bond. In addition to the proficiency level required setting strict in the implementation of the procedure for the appointment of a notary public, in particular regarding the

\footnotetext{
${ }^{12}$ Notohamijojo, 1975, soal - soal pokok filsafat hukum, Jakarta: Gunung Mulia, p.29
} 
Volume 6 Issue 4, December 2019

Nationally Accredited Journal,

Decree No. B/4130/E5/E5.2.1/2019

procedure of the appointment of a notary, so as not to cause an increase in the number of notaries in a region that does not suit your needs, it is according to the author is very influential in reducing the occurrence of violations of the code of conduct in particular unfair competition between fellow notary.

\section{Closing}

\subsection{Conclusion}

- Authority can conclude MKN-W in making recommendations is actually very large, first fired Notary concerned (should qualify as Person A) and degrade in the same authentic deed or deed quality as the document states, in order to be evidence of a Crime. As a result of criminal acts committed by a Person, resulting in degradation of dignity and dignity Notary PPAT as a whole, therefore, no wonder this Law Discussion material will continue.

- Code violations that occur, that a deed that is not in accordance with the Act - Law office of Notary as: certificates that have already been prepared by another notary so that the notary concerned shall stay signed. The signing of the deed which was not done in the presence of a notary, a deed outside the office, the provisions regarding the installation of signs in front of a notary public or in an office environment. The discovery of the notary who made the nameplate exceeds a predetermined size. As well as other code violations notary that their rates of unhealthy competition, where there is a notary who put up a very low tariff to get clients, doing publicity or promotional yourself by stating your name and position.

\subsection{Suggestion}

- Notary public officials appointed by the government, running their positions under oath, should uphold professionalism and values of Pancasila, based on Moral Ethics UUJN and dedication to achieve a disciplined performance, quality and responsibility

- Board of trustees needs to conduct the prosecution firm to provide a deterrent effect to the notary who violates the code of conduct notary consisting of publicity or self-promotion, mounting nameplate, representative offices and establishment of honorarium for the prosecution will uphold the value of honor to the positions and organizational notary

\section{References}

[1] Lili Rasyidi., Check In Darji Darmodiharjo, 2000, Et.Al. Pokok-Pokok Filsafat Hukum (Apa Dan Bagaimana Filsafat Hukum Indonesia), Jakarta: Gramedia Pustaka Utama.

[2] Victor M.Situmorang and Cormentyana Sitanggang, 1993, Grosse Akta dalam Pembuktian dan Eksekusi, Molds 1, Jakarta: Rineka Cipta.

[3] Muchlis Fatahna et al, 2003, Notaris Bicara Soal Kenegaraan, Jakarta: Watampone Press. 
[4] Habib Adjie, 2011, Hukum Notaris Indonesia, Bandung: Refika Aditama, Pg. 188

[5] file: /// C: / Users / asus / Downloads / 213 182-none\% 20 (1) .pdf, Accessed on 30 December 2019, 20:00

[6] Henny Tanuwidjaja, Juridical Aspects Law - Notary Act No. 30 of 2004 Jo Act 2 of 2014 NOmor Performance Against Notary Law Journal Vol. XXX No. December 2nd, 2014

[7] Wawan Setiawan, 2004, Sikap Profesionalisme Notaris Dalam Pembuatan Akata Otentik, Surabaya: Media Notary

[8] Notohamijojo, 1975, soal - soal pokok filsafat hukum, Jakarta: Gunung Mulia 